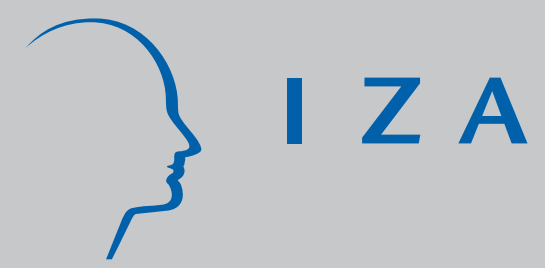

IZA DP No. 4658

Electoral Rules, Political Competition and Fiscal Expenditures: Regression Discontinuity Evidence from Brazilian Municipalities

Marcos Chamon

João M. P. de Mello

Sergio Firpo

December 2009 


\title{
Electoral Rules, Political Competition and Fiscal Expenditures: Regression Discontinuity Evidence from Brazilian Municipalities
}

\author{
Marcos Chamon \\ International Monetary Fund and BREAD \\ João M. P. de Mello \\ Pontifical Catholic University of Rio de Janeiro \\ Sergio Firpo \\ São Paulo School of Economics, FGV and IZA
}

Discussion Paper No. 4658

December 2009

IZA

P.O. Box 7240

53072 Bonn

Germany

Phone: +49-228-3894-0

Fax: +49-228-3894-180

E-mail: iza@iza.org

Any opinions expressed here are those of the author(s) and not those of IZA. Research published in this series may include views on policy, but the institute itself takes no institutional policy positions.

The Institute for the Study of Labor (IZA) in Bonn is a local and virtual international research center and a place of communication between science, politics and business. IZA is an independent nonprofit organization supported by Deutsche Post Foundation. The center is associated with the University of Bonn and offers a stimulating research environment through its international network, workshops and conferences, data service, project support, research visits and doctoral program. IZA engages in (i) original and internationally competitive research in all fields of labor economics, (ii) development of policy concepts, and (iii) dissemination of research results and concepts to the interested public.

IZA Discussion Papers often represent preliminary work and are circulated to encourage discussion. Citation of such a paper should account for its provisional character. A revised version may be available directly from the author. 
IZA Discussion Paper No. 4658

December 2009

\section{ABSTRACT \\ Electoral Rules, Political Competition and Fiscal Expenditures: Regression Discontinuity Evidence from Brazilian Municipalities*}

We exploit a discontinuity in Brazilian municipal election rules to investigate whether political competition has a causal impact on policy choices. In municipalities with less than 200,000 voters mayors are elected with a plurality of the vote. In municipalities with more than 200,000 voters a runoff election takes place among the top two candidates if neither achieves a majority of the votes. We show that the possibility of runoff increases political competition. We use the discontinuity as a source of exogenous variation to infer causality from political competition to fiscal policy. Our results suggest that political competition induces more investment and less current expenditures, particularly personnel expenditures. The impact of political competition is larger when incumbents can run for reelection, suggesting incentives matter insofar as incumbents can themselves remain in office.

JEL Classification: H72, D72, C14, P1

Keywords: electoral systems, political competition, regression discontinuity, fiscal expenditures

Corresponding author:

Sergio Firpo

Escola de Economia de São Paulo - FGV-SP

R. Itapeva, 474/1215

São Paulo, SP 01332-000

Brazil

E-mail: sergio.firpo@fgv.br

\footnotetext{
* We would like to thank Helios Herrera, Leonardo Rezende, Filipe Campante, Alexandre Samy, Claudio Ferraz, and seminar and conference participants at FGV-SP, PUC-Rio, USP, LAMES 2008, NEUDC 2008, PEGLACEA 2009, IPEA-RJ, IBMEC-RJ, UFJF and FGV-RJ for useful comments. Edson Macedo provided excellent research assistance. The views expressed in this paper are those of the authors and should not be attributed to the International Monetary Fund. Usual disclaimer applies.
} 
"How an excess of political stability can get in the way of good government" The Economist, May $17^{\text {th }}$, 2008 commenting on the mishaps of the Concertación, the Chilean long-standing governing coalition.

\section{Introduction}

It is well established that electoral rules have strong implications for the political process. For example, plurality voting favors a two-party system ("Duverger’s Law", Duverger, 1954). By affecting party formation, different electoral rules induce different levels of electoral competition. However, the effects of political competition on policy choices are not well understood empirically. It is not surprising that the empirical link from political competition to policy making can be elusive, as the two are simultaneously determined. While barriers to entry can lead to low competition and bad policies, low competition can also coexist with good policies, if for example a highly capable incumbent discourages entry by challengers. Although a growing body of evidence supports the view that competition improves policy making, ${ }^{1}$ too little a barrier to entry may lead to instability, fragmentation and worse policies. ${ }^{2}$ We explore a unique discontinuity in the rules for municipal elections in Brazil, which provides a sharp identification of how competition improves fiscal policy. Our results indicate that competition improves fiscal policy.

Mayoral elections in Brazil take place every four years, with the election rules varying depending on the size of the electorate. In municipalities with more than 200,000 voters elections are in a two-round system. A runoff between the first-round winner and the

\footnotetext{
${ }^{1}$ See, for example, Besley et al (2005), Besley and Case (1995), Rodgers and Rodgers (2000), and Besley and Case (2003) and Gordon and Huber (2007).

${ }^{2}$ See, for example, Campante et al (2008).
} 
runner-up takes place if the former receives less than 50 percent of valid votes. In municipalities with less than 200,000 voters there is only one round with the winner being the one who gains the most votes. Voting is mandatory in all races. The 200,000 threshold rule provides an exogenous and abrupt change in the voting system as a function of the electorate size. As long as the electoral rules cause "political market" structure, it can be a source of exogenous variation in the degree of competitiveness of the "political market". This discontinuity arguably provides the sharpest identification for the causal effect of political competition on fiscal policy outcomes.

The link from electoral rules to political market structure is well established in the literature. ${ }^{3}$ Most comparisons contrast majority and proportional systems, and why the latter favors multi-party structures. Similar arguments can be made for comparing one-round with two-round majority elections. For example, consider a one-round election and suppose that 60 percent of the electorate is left-leaning. If there is one left-leaning and one right-leaning party contesting the election, the former easily win. But if there are two competing leftleaning parties, the right-leaning one may be able to achieve a plurality of the vote. In this case, the third candidate would be a "spoiler," and in a well functioning system the two leftleaning parties should form a coalition and launch a single candidate. In a two-round election, the presence of the third candidate should not affect the final outcome and therefore we should expect a larger supply of candidates under that system.,

\footnotetext{
${ }^{3}$ See, for example, Duverger's Law, which is formally proved in Palfrey (1989).

${ }^{4}$ Note that the presence of a runoff would not necessarily rule out a right-leaning party victory in this example. Suppose there are four left-leaning parties each of which receives 15 percent of the vote, and two right-leaning parties that receive 20 percent of the vote. Then, a runoff would take place with the two right-leaning parties.

${ }^{5}$ The presence of a runoff is more likely to affect the outcome of the election when voters choose their first choice of candidate (sincere voting) than under strategic voting. The political economy literature has interest in (continued)
} 
Methodologically, we use a regression-discontinuity design (RDD) ${ }^{6}$, which is known for its very high internal validity as it exploits the exogenous variation that occurs around the discontinuity point. Thus, it dispenses with concerns about unobserved heterogeneity driving results. Our empirical results show a discrete and sizeable jump in voting concentration as function of the electorate size and that this jump occurs at the 200,000 voter threshold. That is, there is an abrupt increase in political competition for municipalities where the second round is present. Following the Political Science literature, we measure concentration both as the number of effective candidates as well as the share of votes going to the third-placed or lower candidates. ${ }^{7}$ Thus, the runoff reduces the "political market concentration" by encouraging more parties to enter and/or inducing sincere voting in the first round, thus turning the political regime more competitive. ${ }^{8}$

Under the assumption that the presence of the second round does not affect policy choices directly, it provides exogenous variation to estimate the causal impact of political competition on policy choices. Although one can always conceive reasons for why the presence of the second round per se will affect policy choices, they are rather far-fetched. ${ }^{9}$

sincere versus strategic voting because of their different implications for modeling. Some empirical evidence is available, mainly using structural modeling strategies. See Degan and Merlo (2007) and Merlo (2006).

${ }^{6}$ RDD was introduced by Thistlewaite and Campbell (1960) but has been widely diffused in the empirical economics literature since the work of Van der Klaauw (2002), Angrist and Lavy (1999), Hahn, Todd and Van der Klaauw (2001), among others. See also the recent work of Imbens and Lemieux (2008) for an extensive survey on RDD.

${ }^{7}$ Starting with Laakso and Taagera (1979), the Political Science literature has used the number of effective parties as their main measure of political competition. The number of effective candidates is the inverse of the sum of squared vote shares, i.e., the inverse of the Herfindahl-Hirschman Index of vote shares multiplied by 10,000 .

${ }^{8}$ While revising this paper we came across Fujiwara (2009), which is an independent paper exploring the same discontinuity in electoral rules. His paper only uses the discontinuity to test sincere voting, unlike our paper which uses the RD design as source of exogenous variation in political competition, which is then used to test the effect of differential political competition on policy outcomes.

${ }^{9}$ One possible scenario is the following: When a second round is necessary, new coalitions are formed with first-round losers and thus additional compromises on policies have to be made. This critique does not threaten our identification strategy because the future cannot cause the past: we use political competition at the end to 
Our results indicate that a higher degree of political competition causes more capital expenditures, less expenditures in current expenditures, and more construction of schools. Most of the estimated reduction in current expenditure takes place through lower payroll expenditures. To the extent that Brazilian politicians tend to heavily favor current expenditures and underprovide public investment, this shift is interpreted as welfare enhancing (especially given an under-developed infra-structure). Thus, political competition seems to have beneficial effects. ${ }^{10}$ In contrast with previous works, we do not estimate the effect of political competition on the size of government because in most municipalities the vast majority of expenditures are financed by federal and state transfers, which accounted for almost all of the revenues in our main sample of municipalities with 100,000-300,000 voters. Federal transfers are determined by a formula, as a function of the municipality's population and the per capita income in its state. There are no discontinuities with respect to population in our main sample. ${ }^{11}$

Interestingly, we find much stronger results when we only consider races in which the incumbent could run for reelection. Incumbents do have a stake in their parties staying in power but they respond much more to competition when they themselves can be reelected. This fact is in line with the empirical literature. Using US state-level data, Besley and Case (1995) compare the behavior of governors who face a biding term limit with those who can run for reelections, and find that a biding term limit affects policy choices. Using Brazilian

\footnotetext{
the mandate to proxy for expected political competition. Nevertheless, we compared fiscal policy in cities in which the election went to the second by a small margin to cities whose election was decided in the first round by a small margin, in the spirit of Lee et al (2004). We found no significant difference.

${ }^{10}$ It is consensual among Brazilian economists (within the mainstream of the profession) that current expenditures is excessive while public investment is at a sub-optimal level. See, for example, Werneck (2008).

${ }^{11}$ The last sharp discontinuity in the formula takes place at 156,216 habitants, which involves municipalities that are typically smaller than those with 100,000-300,000 voters.
} 
municipal data, Ferraz and Finan (2008) document that mayors who cannot run for reelection are more corrupt than first-term mayors, who can run for reelection.

Our results are also consistent with previous studies documenting the beneficial effects of political competition at the sub-national level. ${ }^{12}$ For example, Besley et al (2005) use the Voting Rights Act of 1965 to associate an increase in political competition in American Southern states with an improved economic performance measured by income per capita. They show that the Voting Rights Act of 1965 increased political competition. However, the link from political competition to income per capita remains somewhat suggestive, as it is difficult to isolate other factors that may have caused income to increase in the South over a long horizon. In contrast, our paper focuses on policy choices instead of economic outcomes such as income per capita. By focusing on actual policy choices, whose change can be measured in the short-run, we provide a cleaner identification of the effect of political competition to welfare.

Our paper relates to the findings of cross-country comparisons of electoral rules on fiscal policy outcomes. Persson and Tabellini (2004) show that presidential regimes and majoritarian rules lead to smaller governments than parliamentary regimes and proportional representation. Majoritarian rules also tilt the composition towards less transfer expenditures than proportional representation. This last result was also presented and formalized in MilesiFerretti et al (2002). It is difficult to draw comparisons with our setting, since much of these results focused on the distinction between majoritarian and proportional representation, whereas our analysis is limited to the presence of a runoff. But taking the results at face-

\footnotetext{
${ }^{12}$ It is possible that, by reducing the probability of remaining in office, higher political competition worsens policies by shortening the incumbent's horizon. Campante et al (2008) show that stability can have nonmonotonic effects on the quality of policies, which is empirically supported in their cross-country analysis.
} 
value would suggest that increasing political competition through a runoff election can lower current expenditures, whereas increasing political competition through proportional representation (where entry barriers for parties are lower) has the opposite effect.

The paper is organized as follows. In section 2 we describe the institutional background and the data used. Section 3 shows descriptive statistics of our sample and some graphical evidence that the 200,000 rule is exogenous, in the sense that a "no-manipulation" condition is satisfied. In section 4, we discuss in detail how the discontinuity in the voting system allows identification of the causal effect of political competition on fiscal expenditures. In section 5 we present and discuss our main findings. Section 6 concludes.

\section{Institutional Background and Data Description}

Runoff elections were introduced by the 1988 Constitution. Article 29, chapter 4 legislates on municipal elections. Little hard evidence is available on the motivation behind instituting two-round elections. Anecdotes suggest a desire to ensure "legitimate" outcomes by avoiding the risk that a candidate wins a one-round elections with a small share of the votes (the Constitution was written at a time when Brazil was transitioning from twenty years of military rule towards becoming a consolidated democracy). The presidential and all gubernatorial elections have two-rounds. Cost considerations drove the 200,000 threshold for

municipal elections. Voter registration is compulsory and voting is mandatory. Thus, the 
intensity of political competition will not affect whether or not a municipality is above or below the threshold, which would not be the case if voter registration was voluntary. ${ }^{13}$

The first round election takes place sometime in the beginning of October, and the second round sometime between the end of October and early November. ${ }^{14}$ Where the election has only one round, it takes place the same day as the first round. The state-level electoral authority is in charge of counting the number of registered voters per city to define where second round may take place. The electoral authority rests with the Electoral Justice System, which is composed of a federal entity, Tribunal Superior Eleitoral (TSE), and 27 state entities, the Tribunais Eleitorais Regionais (TREs). Although formally a member of the judicial system, the TSE not only judges but also performs executive and legislative tasks. It enacts specific legislation for elections and is co-responsible for the actual execution of the elections (presidential, gubernatorial and mayoral elections). The TREs are responsible for the execution of gubernatorial and mayoral elections. Among the executive tasks are registering voters, resolving litigation among candidates, enforcing electoral legislation, and running the actual voting process. The fact that voters' headcount is done by the state-level TREs dramatically reduces the scope for municipalities to manipulate their electorate size. Moreover, since voting and voter registration are compulsory in Brazil one would have to orchestrate large scale document fraud to manipulate the municipal-level electorate size, something rather far-fetched.

\footnotetext{
${ }^{13}$ The electorate is composed of three groups. All citizens between 18 and 64 years are automatically registered, and voting is mandatory for registered voters. Second, between 16 and 18 registration in optional, but voting is mandatory once registered. Finally, voting is optional for registered voters older than 64 years. Besides fines, sanctions for not voting include becoming ineligible for public sector jobs, passport issuance and, more importantly, government transfers.

${ }^{14}$ In 1996, the first round took place on October $3^{\text {rd }}$, and the second on November $15^{\text {th }}$. In 2000, it took place on October $1^{\text {st }}$ and October $29^{\text {th }}$. In 2004, on October $3^{\text {rd }}$ and October $31^{\text {st }}$.
} 
The Tribunal Superior Eleitoral (TSE) publishes the electoral data. Election results, as well the number of registered voters, are electronically available for a total of 16,498 firstround races over three election cycles: 1996, 2000 and $2004 .{ }^{15}$ The first two-round municipal election took place in 1992 (the first after the 1988 Constitution). Unfortunately, electronic data are not available for $1992 .{ }^{16}$ The analysis focuses on a subset of these races: those that took place in cities with electorate size between 100,000 and 300,000. Although we have information on a large number of races, identification is only credible around the discontinuity threshold 200,000 voters. In 2004, 83 cities were in this range. While this is a small share of the total number of Brazilian municipalities, the combined population covered in our sample is fairly large, with about 28 million inhabitants in 2004 (15.5 percent of the Brazilian population).

We consider four fiscal policy variables: capital, current and payroll expenditures as proportions of total expenditures aggregated over the administration cycle, and the number of municipal public schools built net of schools closed throughout the administration cycle. ${ }^{17}$ Fiscal data come from the Secretaria do Tesouro Nacional, the National Treasury, which is subordinated to the Ministério da Fazenda (the Ministry of Finance). The number of schools at the municipal level is from the Censo Escolar, a universal census of schools conducted annually by the Ministry of Education.

\footnotetext{
${ }^{15}$ The total number of municipalities in Brazil is a little over 5,000. This figure oscillates slightly because of new municipalities, which are normally created by dismembering from another municipality. No municipality around the discontinuity (between 100,000 and 300,000) was dismembered during our sample period, so our results are not affected.

${ }^{16}$ Data is available after the electronic ballot was introduced by Law \# 9.100, from 1995 onwards. The 1996 municipal elections were the first to have electronic ballot in the vast majority of races.

${ }^{17}$ There was a significant expansion of education in Brazil during the sample covered in our study. Primary school net enrollment has been about 95 percent over the last decade. But secondary school net enrollment increased from about 65 percent in the late 1990s to about 80 percent in the most recent years.
} 
Although the size of the government would also be of interest, the vast majority of expenditures in small Brazilian municipalities are financed by transfers from the federal and state governments. This makes the size of municipal governments almost exogenous to the municipal-level political process. ${ }^{18}$

Finally, Brazilian electoral institutions are such that it is quite difficult to find plausible channels for the electoral rule to have a direct effect on fiscal policies, which makes the rule a source of exogenous variation to estimate the impact of political competition on policy making..$^{19}$

The exogeneity of the runoff is confirmed by the actual distribution of electoral size. Figure 1 shows the histogram and kernel density estimate of the electorate size. A significant discontinuity at 200,000 would raise the suspicion that municipalities were manipulating the electorate size. As expected, the histogram shows that the frequency drops almost monotonically with electorate size. The histogram shows a slight drop from bin [186,000 ; $200,000]$ to bin $[200,000 ; 214,000]$, but it is not particularly pronounced compared with other fluctuations in the figure. Still, given the drop in the histogram, we further investigate

18 In our main sample (municipalities between 125,000 and 275,000 voters), overall transfers represent on average roughly 69 percent of revenue. Taxes and fees amounted to another 18 percent, and capital revenues were the remaining 13 percent. Transfers are constitutionally mandated shares on state and federal-level taxes, and are therefore exogenously determined. The two sources of municipal-level sources of income are an urban property tax (IPTU, roughly 4.7 percent of total income) and a tax on services (ISS, with 5.8 percent of total income). The former is highly dependent on property values, and the later on economic activity. Although small changes in tax rates are possible, total income on IPTU and ISS are largely not under the control of incumbents. Finally, except for very large municipalities, Brazilian municipalities do not have access to debt markets, arms' length or banking. Thus, the only of capital revenues is the sale of physical assets, which has clear limits.

${ }^{19}$ We could conjecture only two possible objections to this assumption, none of which seems relevant. One is that, in anticipation to the possibility of a second round, incumbents would invest more to inaugurate public works between rounds. The runoff takes place approximately three weeks after the first round, so this channel seems quite farfetched, particularly since electoral law forbids inauguration for a period before elections. One could also argue that incentives for accepting lobbying money from contractors are higher in two-round elections because one has to finance a longer campaign. However, since rounds are so close in time, the additional campaigning comes at relatively low cost above and beyond that of first-round campaigning. TV advertising is allocated in a centralized manner and is free of charge. Thus, little room is left to spend campaign money between rounds. 
the possibility of manipulation by estimating the density below and above the discontinuity point 200,000, a procedure inspired in McCrary (2008). ${ }^{20}$

\section{[insert Figure 1 here]}

Figure 2A shows a small discontinuity at 200,000, already suggested by the histogram in Figure 1. This tiny discontinuity is neither practically nor statistically significant. ${ }^{21}$ In Figure 2B, we repeat the procedure at 150,000. The discontinuity is larger now, despite the absence of any reason for the electorate distribution to have any discrete change at 150,000.

\section{[insert Figure 2 here]}

\section{Summary Statistics}

Table 1 contains descriptive statistics for all municipalities, as well as for the subsample with $100,000-300,000$ voters that we focus on. Table 1.A contains demographic information. The vast majority of municipalities in Brazil are small: half of the 16,498 races occurred in municipalities whose electorate was smaller than 7,066 voters. Municipalities with electorate size between 100,000 voters and 300,000 are quite different from the average municipality. Races in our sample took place in richer and better educated cities. Interestingly, income inequality within larger cities is not different from the rest of the country. Figure 3 shows an important feature of the data: no relevant discontinuity in income, inequality and education appears at 200,000. Our identification strategy demands the absence of discontinuities in variables that may affect the outcome variables.

\footnotetext{
${ }^{20}$ The procedure consists of two parts. The first stage estimates the histogram in Figure 1. The second stage consists in estimating two local linear regressions, above and below the discontinuity point. The percentage of observations in each bin is treated at the dependent variable, and the midpoint of the bins as regressors. See McCrary (2008) for further details.

${ }^{21}$ We compute the $t$-statistic based on the test proposed in McCrary (2008).
} 


\section{[insert Table 1 here]}

\section{[insert Figure 3 here]}

Table 1.B shows the summary statistics for the political competition variables. The size of electorate and the number of candidates are positively related, which is expected as the size of the political market induces entry. Mayoral races in Brazil have on average 2.78 candidates. In contrast, the 100,000-300,000 voters sample have on average 4.72 candidates. Following the political economy literature, ${ }^{22}$ we use two different measures of political competition: the number of effective candidates, which is the inverse of the HerfindahlHirschman Index (HHI), and the percentage of votes for all candidates except the first and second placed in the first round. The HHI is the sum of squared vote shares. Electoral competition is tougher in our sample than in whole universe of municipalities.

Table 1.C shows some statistics for four fiscal variables: investment as proportion of total expenditures, current expenditures as proportion of total expenditures, payroll as proportion of total expenditures, and the percent increase in the number of municipal public schools. ${ }^{23}$ In the sample covering all municipalities most expenditures (78 percent) go to current expenditures, while 14 percent go to investments. On average, the number of municipal schools grew a little. Municipalities in our 100,000-300,000 electorate size sample are slightly different in terms of fiscal variables. They spend a more on investment and a less

\footnotetext{
${ }^{22}$ Starting with Laakso and Taagera (1979), the literature has used the number of effective parties as their main measure of political competition in the Political Science literature.

${ }^{23}$ The number of observations is lower for the change in municipal schools because data is not available for 1996.
} 
on current, particularly on payroll expenditures, and build more schools. However, differences are not very pronounced.

\section{Estimating Causal Effects}

We are interested in the parameter $\beta_{1}$ given by the following equation:

$$
\text { FISCAL }_{i t}=\beta_{0}+\beta_{1} E\left[\operatorname{POLCOMP}_{i \tau} \mid \tau>t\right]+\varphi_{F}\left(E L E C T_{i t}\right)+\xi_{F, t}+\varepsilon_{i t}
$$

where FISCAL it is a fiscal policy outcome in municipality $i$ at an year $t$ prior to the election year $\tau(t<\tau)$ and POLCOMP $P_{i \tau}$ is the level of political competition in the next election that is expected by the incumbent when making policy decisions over the administration cycle. We measure political competition by concentration of vote shares. The variable ELECT is the size of electorate (number of registered voters). As fiscal policy and political competition may change systematically with the city size, inclusion of $\varphi_{F}(\cdot)$ - a smooth function of electorate - controls this potential source of bias. For the same reason we include $\xi_{F, t}$, to control for year fixed effects. Finally, $\varepsilon_{i t}$ is a function of unobserved shocks to fiscal policy.

The parameter $\beta_{1}$ is the causal effect of the expected competition at election year $\tau$ on policy outcome variables. As mentioned previously, the intensity of political competition is likely to be affected by the quality of policies (reverse causation), so $\operatorname{Cov}\left[\varepsilon_{i t}, P O L C O M P_{i \tau}\right] \neq 0$, and an OLS estimation strategy would fail to recover the causal impact of POLCOMP on policy outcomes. Moreover, political competition is measured with error by construction. Ideally, that variable should be defined as the incumbent's expectation of how competitive the political environment will be in next election. Unfortunately, that 
expectation is not observable. ${ }^{24}$ The alternative often used in the literature on political cycles (which we emulate) is to use actual, realized political competition. In other words:

$$
\operatorname{POLCOMP}_{i \tau}=E\left[\operatorname{POLCOM}_{i \tau} \mid \tau>t\right]+v_{i t}
$$

where $v_{i t}$ is uncorrelated with $E\left[\operatorname{POLCOM}_{i \tau} \mid \tau>t\right]$. In this case, we expect that measurement error causes attenuation bias, which would work against finding an impact of political competition on policy choices when OLS is used.

Therefore, we estimate $\beta_{1}$ in (1) indirectly by the ratio of two reduced form equations. The first reduced form equation relates the actual POLCOMP to DUM200, a flexible polynomial of electorate size, time controls and an unobserved error term:

$$
P O L C O M P_{r}=\gamma_{0}^{P}+\gamma_{1}^{P} D U M 200_{r}+\phi_{P}\left(E L E C T_{r}\right)+\delta_{r}^{P}(t)+\eta_{r}^{P}
$$

where $r$ is electoral race, i.e., a municipality in an election year and $\phi_{P}(\cdot)$ is a flexible polynomial of electorate that may have different functional forms above and below the threshold point. Finally, $\delta_{r}^{P}(t)$ controls for year $t$ fixed effects.

We rewrite the outcome equation (1) using actual instead of the expected of political competition. The parameter of interest is $\beta_{1}$.

$$
\text { FISCAL }_{r}=\beta_{0}+\beta_{1} \text { POLCOMP }_{r}+\varphi_{F}\left(E^{2} E C T_{r}\right)+\xi_{r}^{F}(t)+\zeta_{r},
$$

where $\xi_{r}^{F}(t)$ corresponds to $\xi_{F, t}$ and $\zeta_{r}$ is an unobserved error term.

The reduced-form equation for FISCAL is obtained by replacing POLCOMP in (4) with its specification from (3). The reduced-form equation is:

\footnotetext{
${ }^{24}$ It is conceivable to use opinion polls during the administration cycle. However, these polls are not conducted at a sufficient number of mid-sized municipalities to implement any quantitative empirical procedure.
} 


$$
F I S C A L_{r}=\gamma_{0}^{F}+\gamma_{1}^{F} D U M 200_{r}+\phi_{F}\left(E L E C T_{r}\right)+\delta_{r}^{F}(t)+\eta_{r}^{F}
$$

Straightforward algebra yields $\beta_{1}=\gamma_{1}^{F} / \gamma_{1}^{P}$, which is an implied instrumental variables estimate of the causal effect of political competition on fiscal variables.

We follow a local identification strategy as it is more plausible to assume that any unobserved factor will be randomly assigned to municipalities immediately below and above the 200,000 point. In other words, besides the runoff system, no systematic differences in political competition arise when we compare municipalities on both sides of the threshold. For this reason our empirical analysis is restricted to municipalities in the vicinity of the discontinuity in the electoral rule.

In order to obtain a consistent estimator of the causal effect in a regressiondiscontinuity design, we estimate the models (3) and (5) by modeling $\phi_{P}(\cdot)$ and $\phi_{F}(\cdot)$ as a low-order polynomial, and restrict the data to races with electorate size within a 100,000 window around the 200,000 discontinuity point. ${ }^{25}$ We discuss the details of the implementation in the next section.

\section{Results}

Figure 4 shows how political competition varies with the electorate. We initially regress the political competiton variables on year dummies. We then use the residuals to estimate a linear regression for each side of the discontinuity at 200,000 registered voters.

\footnotetext{
${ }^{25}$ Results are robust to selecting different subsamples. In fact, whe we use narrower sample - e.g., 150,000 through 250,000 - we get stronger results. In addition to estimating the models parametrically as described above, we also estimate them nonparametrically using local linear regression as in Hahn, Todd, and van der Klaauw (2001) as a robustness check. Our nonparametric estimates reveal that the results are robust to specification.
} 
For illustration purposes, each dot in the scatter plot averages represents the local average at each 10,000 range of registered voters. The first four charts show the discontinuities in the share of votes going to the third-placed candidate or lower and in the number of effective candidates. We consider two samples: all races in the 100,000-300,000 electorate size range, and a subsample that includes only races where the mayor could run for reelection.

Before 1997 incumbent mayors, governors and presidents could not run for reelection. In January 1997, Congress amended the Constitution to allow reelection, with at most two consecutive terms. Hence, while incumbent mayors could not run for reelection in 1996, all incumbents could in 2000. In our sample for 2000, 77 percent of the incumbents actually ran for reelection. In 2004, only 52 percent of the incumbents were in their first terms, and could run. Out of those, 91 percent ran for reelection. Our results consider these two samples: all races and races in which the mayor could run for reelection.

As can be seen in Figure 4 a sharp increase in competition arises at the discontinuity threshold. Interestingly, the increase is stronger in the subsample of races where the mayor could run for reelection. The last 4 charts show that the discontinuity result remains robust when the sample is narrowed to a tighter vicinity of the threshold (150,000-250,000 electorate). As expected, no discontinuity arises when we estimate a "placebo" with a discontinuity at 150,000 .

Table 2 reports results from regressions of political competition on the size of the electorate. All regressions include a dummy for 200,000 or more registered voters, and a polynomial of electorate size. In Panel A competition is measured by the vote share of candidates placed third or lower, while in Panel B it is measured by the number of effective candidates. Column (1) considers all races in the 100,000-300,000 electorate range, while 
column (2) restricts the sample to those where the mayor could run for reelection. Columns (3) and (4) are analogous to (1) and (2) but instead of including a quadratic polynomial of electorate size, we allow two different linear functions of electorate size above and below the 200,000 threshold. Consistently with Figure 4, the effect of the discontinuity on political competition is stronger in the subsample of reelections races. All point estimates are statistically significant at the 1 percent level, and point to an increase in the vote share of the third-placed candidates or lower of roughly 60 percent in the whole sample and around 110 percent in the reelection eligible sample. The number of effective candidates increases by 13 percent for the whole sample and 22 percent for the reelection eligible sample. These results are stronger when the sample is restricted to a narrower range of the electorate (e.g. 125,000 to 275,000$)$, and are available upon request.

Turning to the fiscal outcome variables, our identifying assumption is that the discontinuity at 200,000 voters only impacts fiscal policy through its effect on political competition. ${ }^{26}$ We consider three fiscal dependent variables: the logarithms of the share in total expenditures of investment, of current expenditures, and of payroll expenditures. Since yearly data is rather noisy, the dependent variables are the total share over the four-year administration cycle. Additionally, we also measure the impact of political competition on investment in education, measured as the change in the number of schools. For the fiscal variables, three cycles are considered: 1993-1996, 1997-2000 and 2001-2004. Unfortunately, data on the number of schools are only available for the 1997-2000 and 2001-2004 cycles.

\footnotetext{
${ }^{26}$ The municipalities do not bear the costs of the election, so there is no reason why crossing the 200,000 voter threshold should impact fiscal policy other than through political competition.
} 
Figure 5 shows the reduced-form estimates for the fiscal variables. The first two charts show an increase in investment as a proportion of total expenditures, and in the number of schools in the municipality, as a result of crossing the 200,000 electorate threshold. ${ }^{27}$ The increase is much stronger for the races where the mayor could run for reelection. The last four charts show a decline in the share of current expenditures and in the share of payroll expenditures after crossing the 200,000 electorate threshold. The change is very small when all races are considered, but becomes pronounced when the sample is restricted to municipalities where the mayor could run for reelection.

Table 3 reports the reduced-form estimates for the fiscal outcome variables. The regressions are analogous to those in Table 2 (except for the dependent variable), and we again present results for a sample that includes all races in the 100,000-300,000 electorate range, as well as for a subsample including only the races where the mayor could run for reelection. The model in columns (1) and (2) include a quadratic polynomial of electorate size. Columns (1) and (2) show the results for all races and for the reelection subsample respectively. In both samples, crossing the 200,000 voter threshold is associated with higher investment; more schools being constructed; lower payroll and lower current expenditures. There is a 28 percent increase in investment associated with the threshold for all races and a 59 percent increase for the reelection sample. The number of schools increases by 13 percent for all races, and 19 percent for the reelection sample. The share of current expenditures declines by 3 and 5 percent for all races and reelection races, respectively. Payroll expenditures decline by 2 percent for all races and 13 percent for the reelection sample, and

\footnotetext{
${ }^{27}$ It would also be interesting to check how payroll expenditures on teachers behaves as a function of political competition. Unfortunately only total payroll expenditures is only available.
} 
only the latter is statistically significant. It is important to notice that the negative effect of political competition on payroll is stronger than the one on current expenditures as a whole. Payroll expenditures are 50 percent of total outlays. Total current expenditures include payroll expenditures and represent 70 percent of total outlays (see Table 1). Thus, the decline in payroll expenditures accounts for all the reduction in total current expenditures. When a linear polynomial on electorate size is interacted with DUM200 (columns 3 and 4), estimates are stronger that in columns (1) and (2) both in economic and statistical significance. Results are similar (and often stronger) when we focus on a narrower electorate range around the threshold (e.g. 125,000-275,000).

Table 4 presents the causal estimates of political competition on the outcome variables. Results for the whole are not all statistically significant in the reduced form for all four categories. For conciseness, we report only results for the reelection-race sub-sample because these are the only ones that produce systematically significant point estimates. ${ }^{28}$ The estimated elasticity of the share of investment in total expenditures with respect to the vote share going to the $3^{\text {rd }}$ placed candidates or lower range is around 0.60 percent, while the elasticity with respect to the effective number of candidates is around 3.5 percent. This difference in magnitude mainly reflects the smaller variance in the number of effective candidates (see Table 1), with the results broadly comparable when measured in terms of one standard deviation changes in the political competition variables (see paragraph below). The semi-elasticity for the percent change in the number of schools with respect to the percentage of votes to the third and lower candidates is around 19 percent, and the semi-elasticity with

\footnotetext{
${ }^{28}$ We avoid using the sample with all races for estimation of the causal effect since the first stage statistics are not all statistically significant, which could cause the problem of weak instruments..
} 
respect to the number of effective candidates is 106 percent. The elasticity with respect to the vote share of the third placed candidates or lower is roughly 13 percent for the expenditure share of payroll, and around 5 percent for the expenditure share of current expenditures. In both cases the elasticities with respect to the effective number of candidates are again much larger (see columns (3) and (4)).

We gauge the economic significance of these results by focusing on a one standard deviation increase from the mean in the political competition variables. Within the subsample of reelection races, the vote share of candidates placed third or lower has a mean of 17.44 and standard deviation of 12.53. Averaging the effects estimated in columns (1) and (2) a one standard deviation increase from the mean in the vote share of candidates placed third or lower implies a: 35 percent increase in the share of investment in total expenditures; 10 percent increase in the number of schools; and 3 and 7 percent decline in the share of total current expenditures and payroll expenditures, respectively. A one standard deviation increase in the number of effective candidates implies: 55 percent increase in the share of investment in total expenditures; 16 percent increase in the number of schools; and a 5 and a 10 percent decline in the share of total current expenditures and payroll expenditures, respectively. In the sub-sample of reelection races, investment, total current expenditures and payroll expenditures are 13, 50 and 73 percent of total outlays, respectively. Thus, the reduction in payroll expenditures responds for the decline in total current expenditures, and compensates for the increase in investment outlays, leaving the size of government roughly constant. $^{29}$

\footnotetext{
${ }^{29}$ A one-standard deviation change is far for a local impact. Thus we compute the figures as exact percentage effects, not extrapolations of elasticities that are valid only locally. For the elasticities of investment, current
} 
In summary, results suggest that the presence of the second round increases political competition, which in turn cause a reduction in payroll expenditures and an increase in investment expenditures. In particular, more resources are allocated in building schools. Interestingly, the causal impact of political competition is stronger when mayors are eligible for reelection, i.e., when they have a higher stake in staying in office.

\section{Conclusion}

This paper exploited a discontinuity in Brazilian electoral rules to show that runoff elections are associated with more candidates and sharper political competition than majoritarian elections. This result is in line with a large body of theoretical and empirical evidence on electoral rules and electoral competition. An important contribution of our paper is to exploit a quasi-natural experiment that exogenously changes the electoral rule. Thus, among the existing papers on this subject, our design arguably provides the cleanest identification setup for capturing the effect of electoral rules on electoral competition.

Our most interesting result, however, is related to the effect of lower entry costs for political competition on fiscal outcomes. In theory that effect can be ambiguous and lower entry costs may improve or worsen fiscal policy. Also, incumbent politicians can make policy choices that directly affect political competition, which could create a reverse causality problem.

expenditures and payroll expenditures, we use :\% $\% y=100 \times\left(\exp \left(\left(\frac{\text { mean+StDev }}{\text { mean }}\right)^{\widehat{\beta}}\right)-1\right)$. For the semi-elasticity of the percentage change in schools we use: $\Delta y=\hat{\beta} \log \left(\frac{\text { mean+stDev }}{\text { mean }}\right)$. 
However, by taking advantage of the discontinuity in the electoral rule as a function of the electorate size, we can unequivocally identify the causal effect of political competition on fiscal outcomes. Our results suggest that lower political entry costs shift public expenditures from current expenditures towards investment, which can be perceived as welfare improving.

Despite the sharp identification provided by the discontinuity we explore, there are valid concerns relating to external validity. It is likely that the net effect depends on the particular features of the setting. For example, higher competition likely affects young and consolidated democracies differently, and municipalities have less "fiscal levers" to "play with” than national governments. But with these caveats in mind, this paper does suggest that lower costs of political entry in a multi-party democracy are beneficial.

\section{References}

Angrist, J. and V. Lavy, “Using Maimonides’ Rule to Estimate the Effect of Class Size on Scholastic Achievement," Quarterly Journal of Economics, Vol. 114, pp. 533-576, 1999.

Besley, T. and A. Case, "Incumbent Behavior: Vote-Seeking, Tax-Setting and Yardstick Competition,” American Economic Review, Vol. 85, pp. 25-45, 1995.

Besley, T. and A. Case, "Does Electoral Accountability Affect Economic Policy Choices? Evidence from Gubernatorial Term Limits,” Quarterly Journal of Economics, Vol. 110, pp. 769-798, 1995. 
Besley, T. and A. Case, "Political Competition and Policy Choices: Evidence from the United States,” Journal of Economic Literature, Vol. 841, pp. 7-73, 2003.

Besley, T., T. Persson and D. Sturm, "Political Competition and Economic Performance: Theory and Evidence from the United States,” NBER Working Paper Series 11484, 2005.

Black, S., "Do Better Schools Matter? Parental Valuation of Elementary Education,” Quarterly Journal of Economics, Vol. 114, pp. 577-599, 1999.

Campante, F., D. Chor and Q. Do, "Instability and the Incentives for Corruption," SSRN Working Paper, 2008.

Degan, A. and A. Merlo, “A Structural Model of Turnout and Voting in Multiple Elections,” PIER Working Paper 07-011, 2007.

Duverger, Maurice Political Parties, New York: Wiley, 1954.

Fan, J., Gijbels, I., Local Polynomial Modeling and its Applications, Chapman \& Hall, London, 1996.

Ferraz, C. and F. Finan, “Exposing Corrupt Politicians: The Effects of Brazil’s Publicly Released Audits on Electoral Outcomes," Quarterly Journal of Economics, Vol. 123, pp. 703-745, 2008.

Fujiwara, T. "Does Plurality Rule Favors the Two Party System? A Regression Discontinuity Test of Strategic Voting and Duverger’s Law”, Unplished manuscript, 2009.

Gordon, S. and F. Huber, “The Effect of Electoral Competitiveness on Incumbent Behavior,” Quarterly Journal of Political Science, Vol.2, pp. 107-138, 2007. 
Hahn, J., P. Todd and W. Van der Klaauw, "Identification and Estimation of Treatment Effects with Regression Discontinuity Design,” Econometrica, Vol. 69, pp. 201209, 2001.

Imbens, G. and T. Lemieux, "Regression Discontinuity Designs: a Guide to Practice,” Journal of Econometrics, Vol. 142, pp. 615-635, 2008.

Jones, M. Electoral Laws and the Survival of Presidential Democracies, Notre Dame: University of Notre, 1995.

Laakso, M. and Taagepera, R. "The "Effective" Number of Parties: a Measure with Application to Western Europe,” Comparative Political Studies, Vol 12, pp. 3-28, 1979.

Lee, D., "Randomized Experiments from non-Random Selection in U.S. House Elections,” Journal of Econometrics, Vol. 142, pp. 675-697, 2008.

Lee, D., E. Moretti and M. Butler, "Do Voters Affect or Elect Policies? Evidence from the US House,” Quarterly Journal of Economics, Vol. 103, pp. 807-859, 2004.

Lemieux, T. and M. Milligan, "Incentive Effects of Social Assistance: a Regression Discontinuity Approach,” Journal of Econometrics, Vol. 142, pp. 807-828, 2008.

McClintock, C., "Plurality versus Runoff Rules for the Election of the President in Latin America: Implications for Democracy," Annals of the Meeting of the American Political Science Association, 2007.

McCrary, J. "Manipulation of the Running Variable in the Regression Discontinuity Design: a Density Test,” Journal of Econometrics, Vol. 142, pp. 698-714, 2008.

Merlo, A., "Whither Political Economy? Theories, Facts and Issues," in Advances in Economics and Econometrics, Theory and Applications: Ninth World Congress of the 
Econometric Society, eds. Blundell, R., W. Newey and T. Persson, Cambridge: Cambridge University Press, 2006.

Milesi-Ferretti, R. Perotti and M. Rostagno, "Electoral Systems and Public Expenditures,” Quarterly Journal of Economics, Vol. 107, pp. 609-657, 2002.

Palfrey, T. “A Mathematical Proof of Duverger's Law,” in Models of Strategic Choice in Politics, ed. Ordeshook, P., Ann Arbor: The University of Michigan Press, 1989.

Persson, T. and G. Tabellini, "Constitutional Rules and Fiscal Policy Outcomes,” American Economic Review, Vol. 94, p. 25-45, 2000.

Rodgers, D. and J. Rodgers, “Political Competition and State Government Size: Do Tighter Produce Looser Budgets?” Public Choice, Vol. 105, pp. 1-20, 2000.

Thistlewaite, D. and D. Campbell, “Regression-Discontinuity Analysis: An Alternative to the Ex Post Facto Experiment,” Journal of Educational Psychology, Vol. 51, pp. 309-317, 1960.

Van Der Klaauw, W., "Estimating the effect of financial aid offers on college enrollment: a regression-discontinuity approach,” International Economic Review, Vol. 43, pp. 1249-1287, 2002.

Werneck, R. "The Rocky Road to Countercyclical Fiscal Policy in Brazil”, Manuscript, PUC-Rio, Brazil, Department of Economics. 
Table 1. Descriptive Statistics for Municipal Election Races

\begin{tabular}{|c|c|c|c|c|}
\hline \multicolumn{5}{|l|}{ Table 1.A: Demographics } \\
\hline & Mean & Std Dev & Median & Num. Obs. \\
\hline & \multicolumn{4}{|c|}{ Panel A: All Races } \\
\hline Size of Electorate & 19,498 & 126,585 & 7,066 & 16,498 \\
\hline Income per Capita ${ }^{a}$ & 169.23 & 97.37 & 157.63 & 16,674 \\
\hline Gini Coefficient & 0.55 & 0.08 & 0.56 & 16,674 \\
\hline \multirow[t]{2}{*}{ Average Years of Schooling ${ }^{\mathrm{b}}$} & 4.00 & 1.34 & 4.05 & 16,674 \\
\hline & \multicolumn{4}{|c|}{ Panel B: Races With $100,000-300,000$ Voters } \\
\hline Size of Electorate & 159,105 & 48,991 & 143,661 & 282 \\
\hline Income per Capita $^{\mathrm{a}}$ & 333.82 & 46.13 & 318.67 & 282 \\
\hline Gini Coefficient & 0.56 & 0.01 & 0.56 & 282 \\
\hline Average Years of Schooling ${ }^{\mathrm{b}}$ & 6.49 & 0.39 & 6.36 & 282 \\
\hline \multicolumn{5}{|l|}{ Table 1.B: Political Competition Variables } \\
\hline & Mean & Std Dev & Median & Num. Obs. \\
\hline & \multicolumn{4}{|c|}{ Panel A: All Races } \\
\hline Number of Candidates & 2.78 & 1.12 & 2.00 & 16,498 \\
\hline Effective Number of Candidates ${ }^{c}$ & 2.20 & 0.55 & 1.99 & 16,498 \\
\hline \multirow[t]{2}{*}{ Share of Votes of Third Placed and Lower ${ }^{\mathrm{d}}$} & 7.26 & 11.42 & 0.00 & 16,498 \\
\hline & \multicolumn{4}{|c|}{ Panel B: Races With 100,000-300,000 Voters } \\
\hline Number of Candidates & 4.72 & 1.51 & 5.00 & 282 \\
\hline Effective Number of Candidates ${ }^{c}$ & 2.67 & 0.62 & 2.65 & 282 \\
\hline Share of Votes of Third Placed and Lower ${ }^{\mathrm{d}}$ & 19.44 & 12.24 & 18.49 & 282 \\
\hline \multicolumn{5}{|c|}{ Table 1.C: Fiscal Policy Outcomes (Second Stage Variables) } \\
\hline & Mean & Std Dev & Median & Num. Obs. \\
\hline & \multicolumn{4}{|c|}{ Panel A: All Sample } \\
\hline Investment as \% of Total Expenditures & 14.68 & 6.65 & 13.44 & 7428 \\
\hline Current Expenditures as \% of Total Expenditures & 77.94 & 7.21 & 73.25 & 7413 \\
\hline Payroll Expenditures as \% of Total Expenditures & 58.59 & 8.29 & 58.66 & 7413 \\
\hline \multirow[t]{2}{*}{ \% Change in Number of Schools } & 3.51 & 95.69 & 0.00 & 10,798 \\
\hline & \multicolumn{4}{|c|}{ Panel B: Races With 100,000-300,000 Voters } \\
\hline Investment as \% of Total Expenditures & 15.23 & 7.48 & 14.14 & 224 \\
\hline Current Expenditures as \% of Total Expenditures & 71.99 & 14.48 & 73.25 & 221 \\
\hline Payroll Expenditures as \% of Total Expenditures ${ }^{c}$ & 49.44 & 15.53 & 46.43 & 221 \\
\hline \% Change in Number of Schools & 9.69 & 25.70 & 5.83 & 196 \\
\hline
\end{tabular}

Source: Tribunal Superior Eleitoral, Secretaria do Tesouro Nacional and Instituto Brasileiro de Geografia e Estatística. ${ }^{a}$ In 2000 reais. ${ }^{b}$ Years of schooling for the population between 15 and 64 years old. ${ }^{c}$ The number of effective candidates is the inverse of the Herfindahl-Hirschman Index (HHI) multiplied by $10,000 .{ }^{d}$ Percentage of votes received by candidates placed third or lower in the first round. 


\section{Table 2. Effect of Electorate Size on Electoral Competition}

Panel A: Dependent Variable: Log(100-Vote Share of Top Two Candidates)

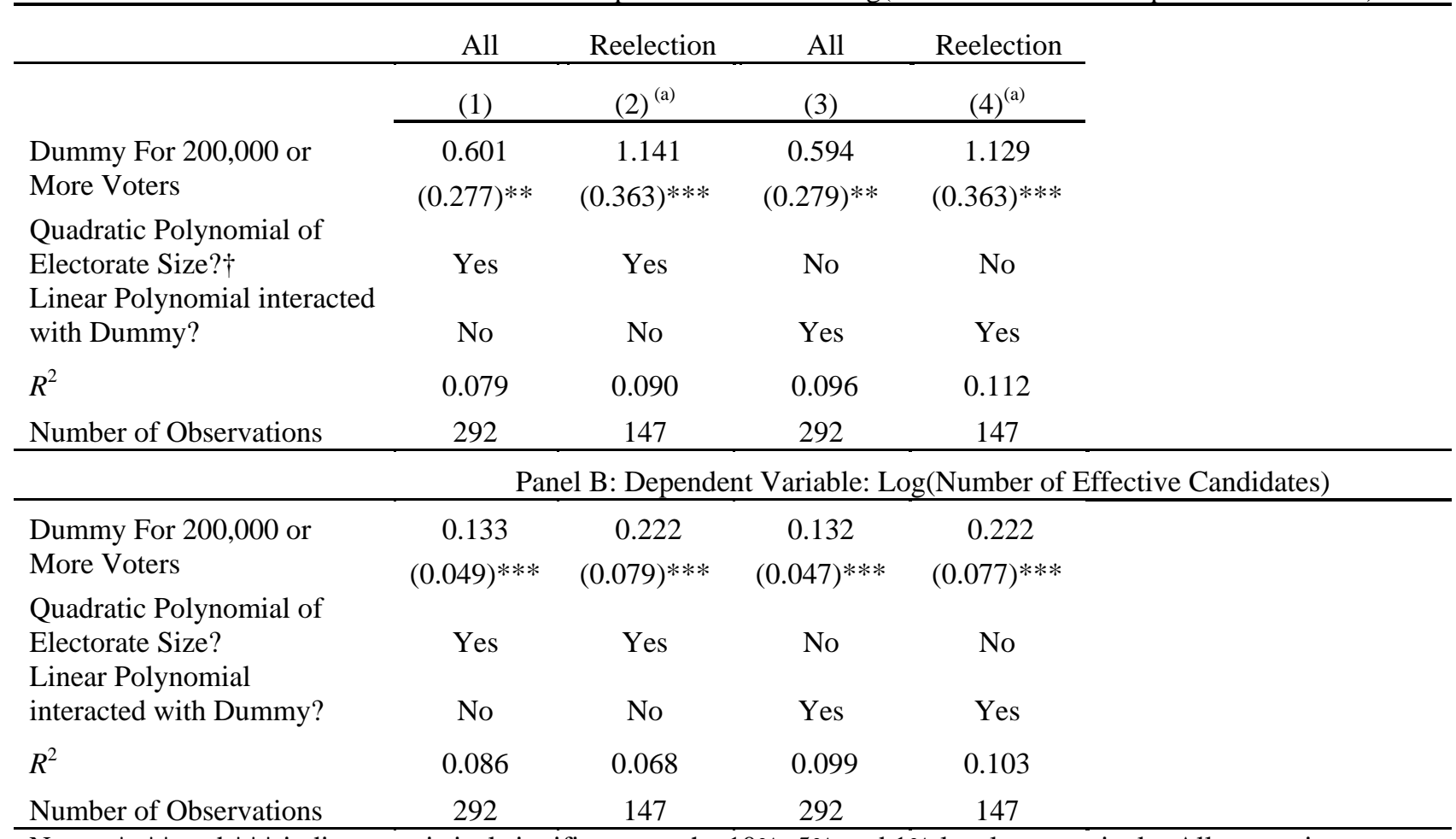

Notes: ${ }^{*}, * *$ and $* * *$ indicate statistical significance at the $10 \%, 5 \%$ and $1 \%$ levels respectively. All regressions include year dummies.

†: Polynomial is (Electorate size- 200,000) and (Electorate size- 200,000) ${ }^{2}$

(a): Sample restricted to races in which the mayor could run for reelection. 


\section{Table 3. Reduced Form Estimates for the Effect of Political Competition on Policy Outcomes}

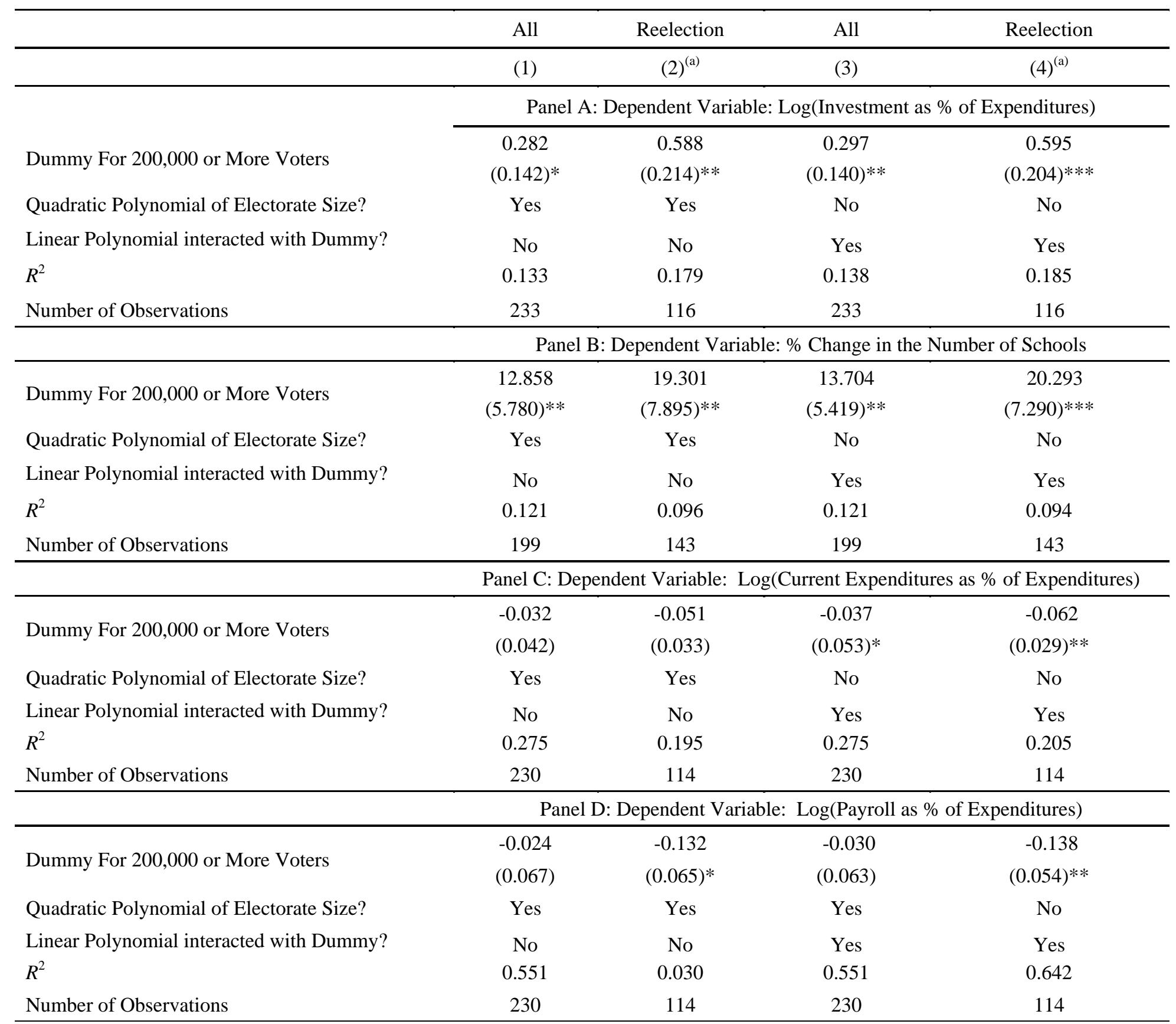

Notes: $* * *$ and $* * *$ indicate statistical significance at the $10 \%, 5 \%$ and $1 \%$ levels respectively. All regressions include year dummies. $\dagger$ : Polynomial is (Electorate size- 200,000) and (Electorate size- 200,000) ${ }^{2}$

(a): Sample restricted to races in which the mayor could run for reelection. 
Table 4. Causal Effect of Political Competition on Policy Outcomes: only reelection races

\begin{tabular}{|c|c|c|c|c|}
\hline & $(1)$ & $(2)$ & (3) & (4) \\
\hline Regressor: & \multicolumn{2}{|c|}{$\begin{array}{c}\text { Log(100-Vote Share of Top Two } \\
\text { Candidates) }\end{array}$} & \multicolumn{2}{|c|}{ Log (Number of Effective Candidates) } \\
\hline & \multicolumn{4}{|c|}{ Panel A: Dependent Variable: Log(Investment as \% of Expenditures) } \\
\hline Causal Effect (Elasticity) & $0.557 *$ & $0.609 *$ & 3.484 & 3.795 \\
\hline Quadratic Polynomial of Electorate Size? & Yes & No & Yes & No \\
\hline Linear Polynomial interacted with Dummy? & No & Yes & No & Yes \\
\hline \multirow[t]{2}{*}{ Number of Observations } & 116 & 116 & 116 & 116 \\
\hline & \multicolumn{4}{|c|}{ Panel B: Dependent Variable: \% Change in the Number of Schools } \\
\hline Causal Effect (Elasticity) & 18.433 & $19.492 *$ & $106.036^{*}$ & $106.361^{* *}$ \\
\hline Quadratic Polynomial of Electorate Size? & Yes & No & Yes & No \\
\hline Linear Polynomial interacted with Dummy? & No & Yes & No & Yes \\
\hline \multirow[t]{2}{*}{ Number of Observations } & 143 & 143 & 143 & 143 \\
\hline & \multicolumn{4}{|c|}{ Panel C: Dependent Variable: Log(Current Expenditures as \% of Expenditures) } \\
\hline Causal Effect (Elasticity) & -0.048 & -0.063 & -0.297 & -0.387 \\
\hline Quadratic Polynomial of Electorate Size? & Yes & No & Yes & No \\
\hline Linear Polynomial interacted with Dummy? & No & Yes & No & Yes \\
\hline \multirow[t]{2}{*}{ Number of Observations } & 114 & 114 & 114 & 114 \\
\hline & \multicolumn{4}{|c|}{ Panel D: Dependent Variable: Log(Payroll as \% of Expenditures) } \\
\hline Causal Effect (Elasticity) & -0.125 & $-0.140 *$ & -0.771 & -0.855 \\
\hline Quadratic Polynomial of Electorate Size? & Yes & No & Yes & No \\
\hline Linear Polynomial interacted with Dummy? & No & Yes & No & Yes \\
\hline Number of Observations & 114 & 114 & 114 & 114 \\
\hline
\end{tabular}

$* * *=$ significant at the $1 \%$ level, $* *=$ significant at the $5 \%$ level, $*=$ significant at the $10 \%$ level 
Figure 1. Distribution of Electorate Size Histogram and Estimated Density of Electorate in 100,000-300,000 Voter Range

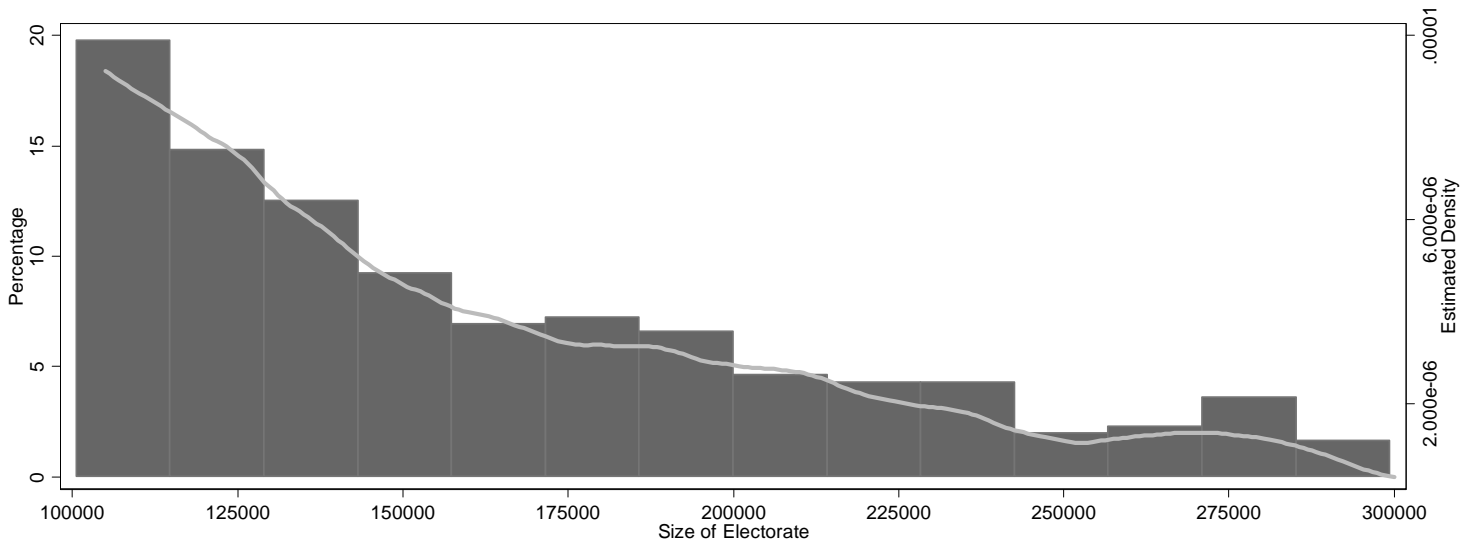

Note: Kernel Density Estimated with Epanechnikov Kernel

Figure 2. Discontinuities in the Estimated Density of Electorate 2.A Discontinuity at 200,000 Voters

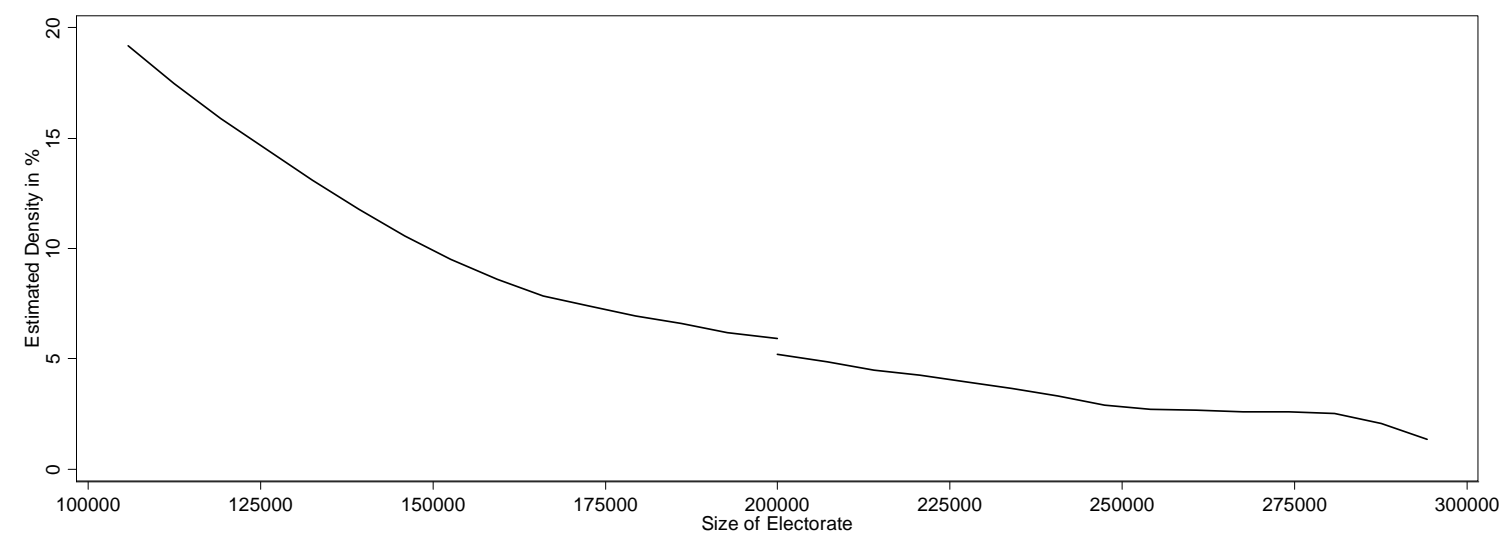

Notes: Using McCrary’s Local Linear Procedure with Triangular Kernel (width of 30,000 and bin of 14,000).

2.B. Discontinuity at 150,000 Voters.

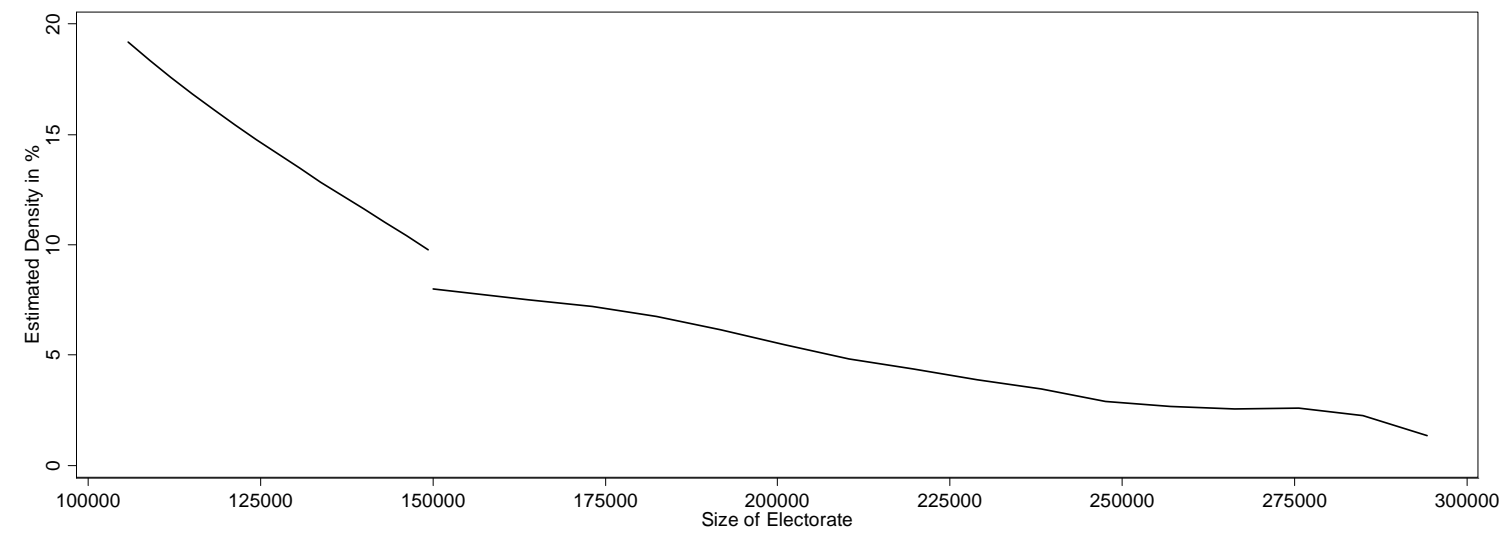

Notes: Using McCrary's Local Linear Procedure with Triangular Kernel (width of 30,000 and bin of 14,000). 
Figure 3. Income and Demographic Sample Statistics for Races Around the Discontinuity at 200,000 Registered Voters:
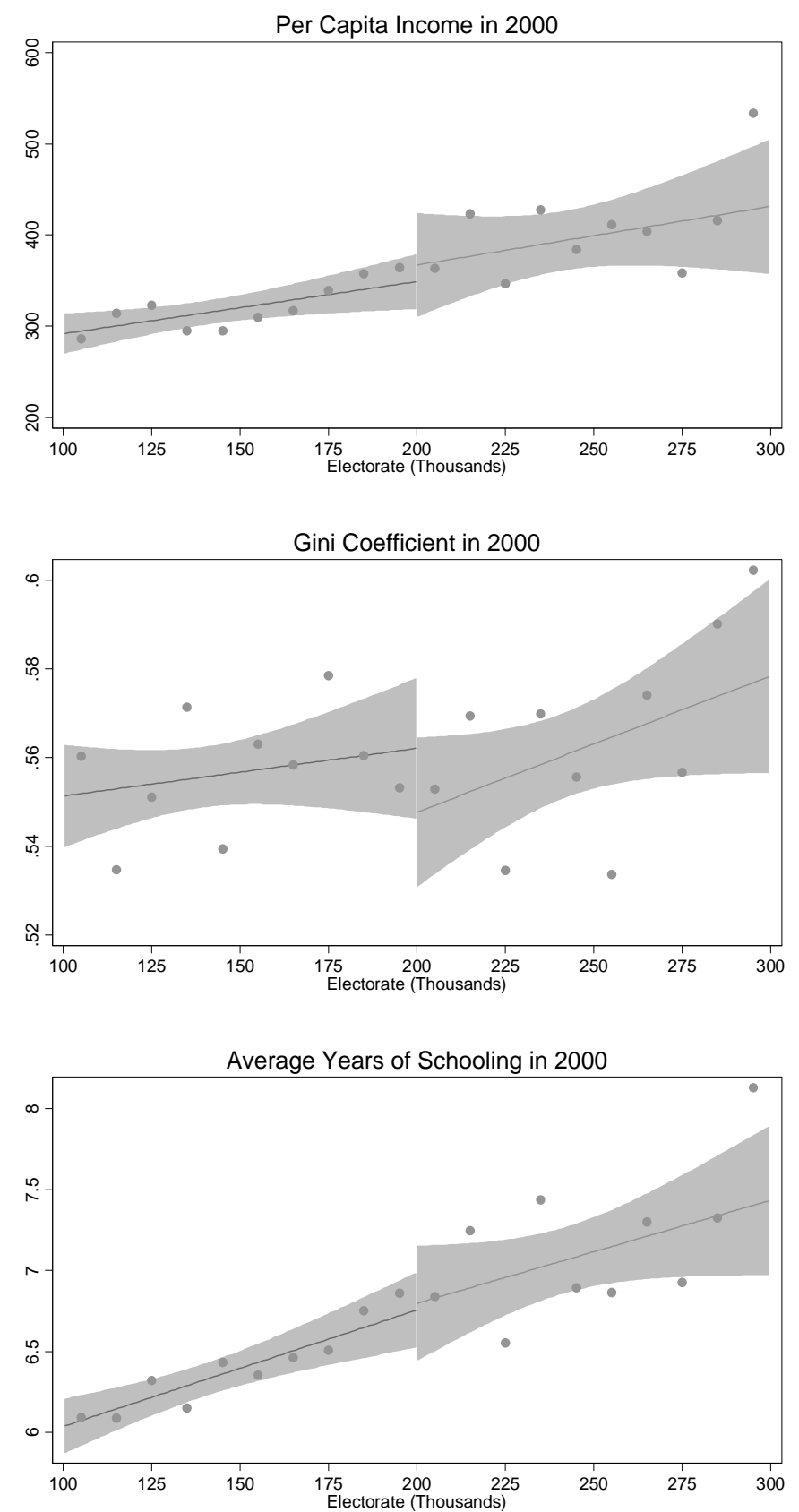

Notes: Plots show the estimated linear regression for each side of the discontinuity. Shadowed area corresponds to the 90 percent level confidence interval. Scattered points indicate averages for each 10 thousand electorate range interval. Due to the low frequency with which income, inequality and schooling data is available, we plotted the year 2000 value of these variables for each observation in our sample. 
Figure 4. Reduced Form Estimates for Political Competition:

Residuals from a Regression on Year Dummies; Discontinuity at 200,000 Registered Voters
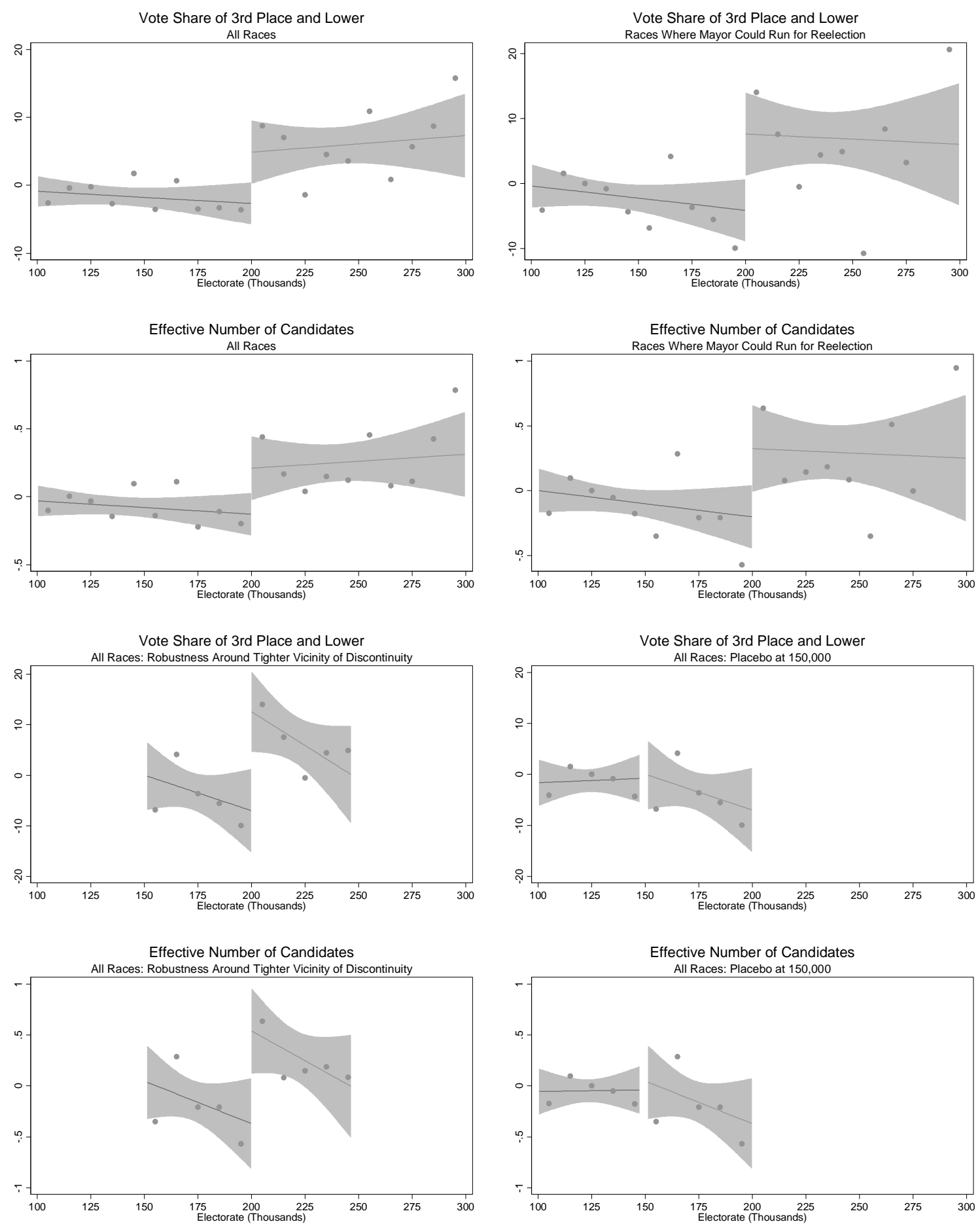

Notes: Variables initially regressed on year dummies. Plots show the estimated linear regression of residuals for each side of the discontinuity. Scattered points indicate averages for each 10 thousand electorate range interval. Shadowed area corresponds to the 90 percent level confidence interval. Statistical significance is implied when the estimated line in one range lies outside of the confidence interval for the other range (as is the case in all figures except those for the placebo). 
Figure 5. Reduced Form Estimates for Fiscal Policy Outcomes:

Residuals from a Regression on Year Dummies; Discontinuity at 200,000 Registered Voters
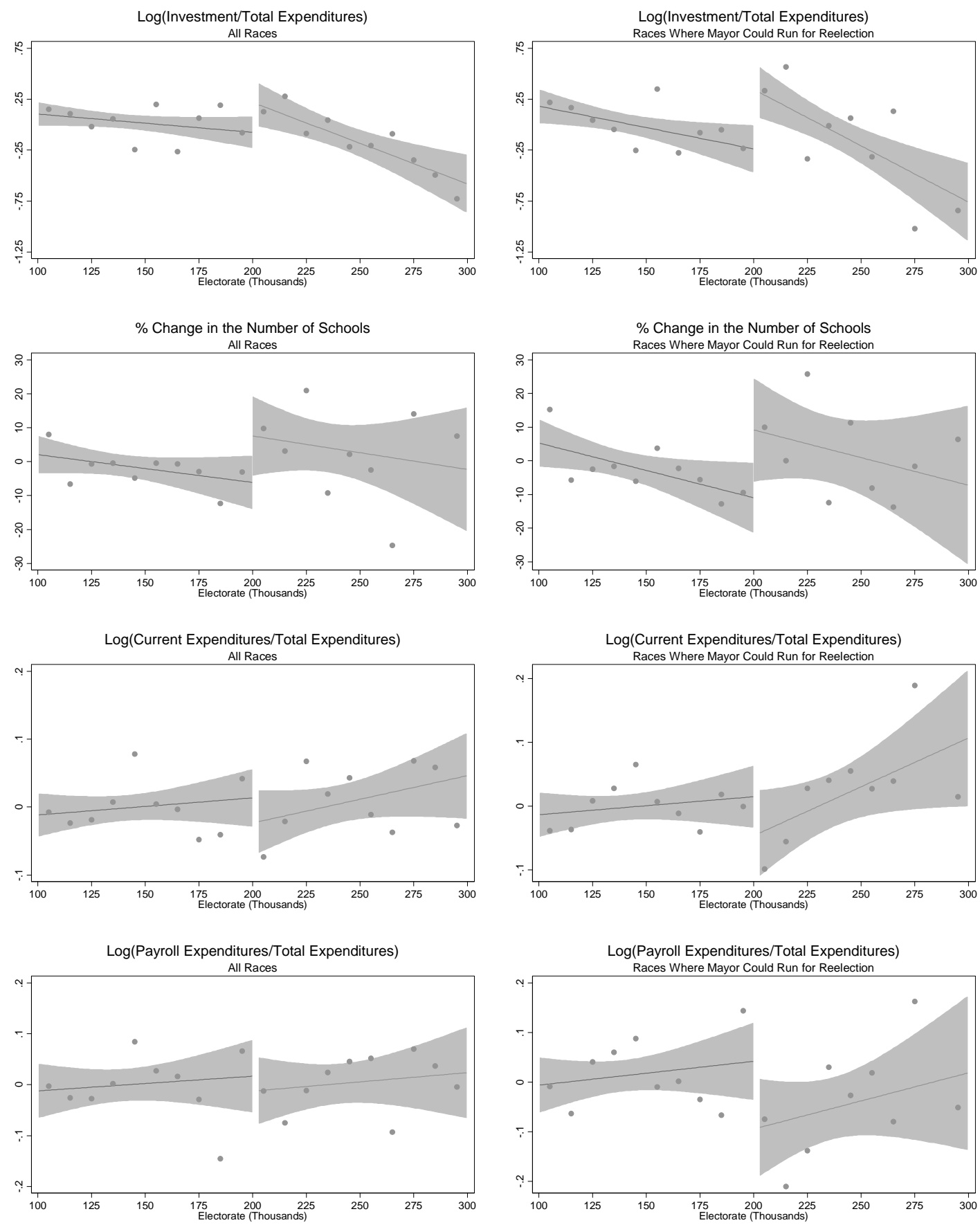

Notes: Variables initially regressed on year dummies. Plots show the estimated linear regression of residuals for each side of the discontinuity. Scattered points indicate averages for each 10 thousand electorate range interval. Shadowed area corresponds to the 90 percent level confidence interval. Statistical significance is implied when the estimated line in one range lies outside of the confidence interval for the other range. That is the case in all graphs except the ones for current expenditure, and the one for payroll with all races. 